\title{
Neuro-cognitive Underpinning of Co-morbidity between Developmental Dyslexia and Attention-Deficit Hyperactivity Disorder (ADHD)
}

\section{Нейрокогнітивні основи коморбідності вікової дислексії та гіперактивного розладу з дефіцитом уваги (ГРДУ)}

\section{Larysa Zasiekina}

Ph.D. in Psychology, Professor

Full Professor in Psychology,

Fulbright (USA) and

Chevening (UK) Scholar
Лариса Засккіна

доктор психологічних наук, професор, стипендіат програм

імені Фулбрайта (США)

та Чівнінг (Велика Британія)

E-mail: lora.zasyekina@gmail.com orcid.org/0000-0001-8456-0774

Reseracher ID: C-3244-2016

National University

"Ostroh Academy»

2, Seminarskya Str., Ostroh,

Ukraine, 35800
Начіональний університет «Острозька академія»

$\triangle$ вул. Семінарська, 2, Острог, Україна, 35800

Original manuscript received April 02, 2018

Revised manuscript accepted October 24, 2018

\section{ABSTRACT}

Developmental Dyslexia is a specific reading and writing disability despite of normal intelligence, educational instruction and socio-cultural opportunity. Attention-deficit hyperactivity disorder (ADHD) is a condition that affects millions of children and often persists into adulthood. ADHD can include a combination of problems, such as difficulty sustaining attention, hyperactivity and impulsive behaviour. The frequent co-morbidity of dyslexia and ADHD posed the question of the issue whether common causal mechanism can be identified. There are several causal explanation of the co-morbidity between 
dyslexia and $A D H D$. Firstly, the symptoms of ADHD associated with dyslexia are a secondary consequence of reading problems ('phenocopy' hypothesis). However, the finding could not substantiate in later studies. Therefore, the first aim the present research is to identify the frequency and nature of co-morbidity between dyslexics and ADHD children.

Developmental Dyslexia and ADHD are some of the most complex developmental disorders that affect children population. These are some of the conditions which affect the ability of the children to benefit from education and engage with surroundings in a meaningful manner. These conditions may occur in isolation, but many times they overlap. These overlapping conditions are termed as co-morbidity, and this may reflect the greater difficulties experienced by the children with a combination of deficits. However, the underlying reasons for these and the subsequent behavioural deficits are not well understood. Thus, the second major goal of the article is to investigate neuro-cognitive underpinning of dyslexia and ADHD. Neuro-cognitive basis presented by prefrontal dorsolateral cortex dysfunction was revealed and executive functions presented by problems in phonological working memory, initiating the activity and multitasking were established.

Key words: $A D H D$, dyslexia, comorbidity, neuro-cognition, reading, executive functions.

\section{Вступ}

Коморбідність вікової дислексії і ГРДУ є доволі поширеною. Близько 25-40\% дітей 3 дислексією одночасно демонструють симптоми ГРДУ (Agust et al., 1990; Willcutt et al., 2000). Результати досліджень свідчать про те, що тоді як при наявності одного розладу: лише ГРДУ чи вікової дислексії спостерігаються мінімальні мозкові дисфункції, сполучення цих розладів часто призводять до глибших нейрофізіологічних порушень. Мінімальні мозкові дисфункції розглядаються нами як незначні структурні порушення у центральній нервовій системі при ушкодженні мозку. Також при наявності одного з розладів можуть спостерігатися легкі мозкові дисфункції, при яких структура мозку не порушена, водночас зустрічаються нейрохімічні і нейрофізіологічні зміни.

Вікова дислексія - це специфічна нездатність оволодівати навичками читання i письма при збереженні нормальних інтелектуальних здібностей та соціокультурної адаптації. За статистикою близько 5-10\% мають симптоми дислексії. Незважаючи на наявність різних підходів до вивчення вікової дислексії: теорії 
фонологічного дефіциту короткотривалої вербальної пам'яті, когнітивно-графічної сегментації тексту i т. ін., найпоширенішим підходом $€$ вивчення дислексії як здатності індивіда до фонологічного усвідомлення (Khan et al., 2017).

Фонологічне усвідомлення - це метакогнітивна здатність, яка забезпечує упізнання i рефлексію мовної системи, зокрема iï фонологічної структури у вигляді складів, рими та фонем. Фонологічне усвідомлення часто ототожнюють із акустикою (акустичним сприйняттям), водночас ці процеси різні. Фонологічне усвідомлення - це процес, спрямований на усвідомлення i ефективне використання фонемами. Акустичне сприймання - це процес, спрямований на визначення букв у конкретних звукових (фонетичних) зразках, використання правил писання та їх використання в кодуванні (письмі) і декодуванні мовлення (читання).

Висока частотність коморбідності вікової дислексії і ГРДУ дає змогу зробити припущення про спільні нейрокогнітивні механізми цих розладів. Існують кілька припущень стосовно такого поєднання двох розладів: симптоми ГРДУ сукупно з дислексією $є$ похідними від проблем у мовленнєвій діяльності, зокрема такому іiі виді, як читання (гіпотеза фенокопії); або як когнітивна дисфункція, що зумовлює наявність обох розладів (гіпотеза когнітивного розвитку) (Khan et al., 2017). Нестача комплексних досліджень 3 цісї проблеми, 3 одного боку, та збільшення розладу ГРДУ в українських дітей i невизначеність природи дислексії, пов'язаної з будовою української мови, 3 іншого - зумовлює необхідність такого дослідження та його актуальність.

Метою дослідження $є$ теоретико-емпіричне дослідження нейрокогнітивних особливостей коморбідності вікової дислексії і ГРДУ у дітей на основі ефективності здійснення екзекутивних функцій.

ГРДУ - це розлад, який охоплює близько $3-5 \%$ дітей відповідно до DSM-V (American Psychiatric Association, 2002). Результати дослідження спільного українсько-індійського проекту 3 цієї проблеми свідчать про те, що в Індії цей відсоток зростає до 5-15\%, а в Україні 18,8\% (Khan et al., 2017). Ситуація в Україні часто пов'язується із Чорнобильською катастрофою та впливом радіаційних токсинів, пережитого стресу вагітними жінками під час цих подій та необхідністю міграції в різні регіони України 
(Gadow, 2002; Zasiekina, 2009, 2012). Провідними діагностичними критеріями для ГРДУ $є$ постійний i довготривалий прояв неуважності та імпульсивності. Також зустрічаються типи лише 3 дефіцитом уваги, або лише 3 імпульсивністю і гіперактивністю (American Psychiatric Association, 2002).

Значне розходження у фонологічних системах різних мов зумовлює актуальність крос-культурних досліджень цієї проблеми. Так, розбіжності у фонологічній системі української мови та деванагарі дає змогу здійснити крос-культурне психолінгвістичне дослідження нейрокогнітивної обробки вербальної інформації на матеріалі хінді і української мови. Адже девангарі демонструє відповідність звуків на рівні фонем і складів, тоді як українська мова на рівні - лише фонем.

Можна припустити, що коморбідність ГРДУ i дислексії збільшується за наявності складних мовних систем, де правила читання є доволі громіздкими. Водночас розуміння природи ГРДУ дає змогу припустити, що основні симптоми цього розладу не сприяють ефективному читанню на матеріалі будь-якої мови.

До основних базових симптомів ГРДУ належать неуважність, гіперактивність і імпульсивність. Розглянемо їх більш докладно.

Неуважність - це симптом, який вирізняє дітей 3 ГРДУ (комбінованого типу або 3 переважанням неуважності) 3-поміж інших дітей. Результати нейропсихологічних досліджень цих дітей свідчать про те, що зазвичай у них не виникають труднощі в автоматичній діяльності 3 візуально-просторовою інформацією, яка контролюються тім'яними ділянками мозку, водночас основні проблеми починаються при обробці інформації, яка потребує певних когнітивних зусиль та утримання уваги. В. Дуглас у своїх працях називає цей феномен пильністю (Douglas, 1983).

Важливою проблемою, пов'язаною із цим симптомом, $\epsilon$ відволікання на різні другорядні стимули, які не зумовлені конкретною діяльністю. Проблема 3 відволіканням часто пов'язується $з$ іншими когнітивними проблемами або особливостями завдання - надто ускладнене завдання, надлишкове когнітивне навантаження, труднощі 3 робочою пам'яттю, а також проблеми у прогнозуванні, виконанні і контролі діяльності.

Саме серед неуважних дітей з ГРДУ виокремлюють найбільшу частку дітей із уповільненим когнітивним темпом. Хоча у визначенні 
типів ГРДУ ці діти не виділені в окрему групу, спостерігається чітка тенденція до їх дослідження, оскільки вони вирізняються певними характеристиками: пасивні, мляві, гіпоактивні, часто дивляться в одну точку та дуже повільно рухаються. Водночас такі діти мають свої особливості порівняно з дітьми комбінованого типу ГРДУ. Їх симптоми є більшою мірою інтерналізовані, ніж виражені ззовні: депресія, тривожність, соціальна ізольованість. Результати досліджень Р. Барклі показали, що діти з уповільненим когнітивним темпом мають значні труднощі в обробці інформації, фокусуванні уваги, активізації пам'яті (Barkley, 2006).

На теперішній момент виокремлюють два основних види неуважності, які по-різному впливають на прояви ГРДУ: неуважність як відволікання i неуважність як мрійливість і уповільненість. Перший вид як відволікання $\epsilon$ найбільш вивченим як 3 позиції визначення його природи, так і виділенні діагностичних критеріїв. Саме цей вид уваги представлений діагностичними критеріями у статистичному i діагностичному довіднику психічних розладів, а також вимірюється поведінковими шкалами для визначення ГРДУ. Інший тип неуважності вирізняється уповільненою природою, що визначає надлишкову мрійливість, відсторонення, пасивність. Саме цей вид неуважності збігається із уповільненим когнітивним темпом, який, на думку багатьох вчених, у найближчому майбутньому виокремиться ще в один тип ГРДУ.

Інший важливий симптом досліджуваного розладу імпульсивність. Подібно до неуважності, яка може бути багато модальною за своєю природою, імпульсивність теж має різні аспекти свого прояву. На думку вчених, імпульсивність є однією 3 найважливіших характеристик ГРДУ (Barkley, 2006; Zasiekina, 2009). Результати їхніх досліджень свідчать про те, що неуважність не такою мірою відрізняє дітей з ГРДУ від дітей контрольної групи, як імпульсивність, гіперактивність, низький контроль над поведінкою. Вчені зазначають про існування так званого ендофенотипу ГРДУ, оскільки він охоплює відносно постійні симптоми ГРДУ, які мають генетичну і нейропсихологічну природу.

Останній, але не менш важливий симптом ГРДУ, гіперактивність. Цей симптом певною мірою пов'язаний із імпульсивністю і виражається у підвищеній моторній і вербальній активності. Результати факторного аналізу не дають змогу 
виокремити імпульсивність в окрему групу симптомів, тому остання часто розглядається в групі з гіперактивністю.

Важливим підрозділом у діагностичному i статистичному довіднику психічних розладів $є$ вплив соціально-психологічних чинників на природу розладу: культури, віку і статі. Відповідно до чинника культури зазначається про домінування ГРДУ серед високорозвинених західних країн, хоча така розбіжність може пояснюватися різними дослідницькими форматами ГРДУ діагностичними методами, психотерапією i корекцією різних проявів. Щодо вікового чинника вказується на значні труднощі у визначенні ГРДУ у ранньому дитинстві до 4-5 років. Оскільки активність i імпульсивність притаманна дитячому віковому періоду загалом. Найповніше ці симптоми починають виявлятися у шкільному періоді дитини, коли вона зустрічається із значними труднощами у навчанні.

На сучасному етапі значно зростає інтерес до прояву ГРДУ у дорослому віці, адже як засвідчила практика, цей розлад 3 віком часто не зникає, і негативно впливає на різні сфери життя зрілої людини. Зокрема, особи з ГРДУ не можуть працювати на місцях, які потребують уважності чи перебування на одному місці. Зазвичай ці люди страждають на цей розлад із самого дитинства. Водночас, якщо $з$ певних причин розлад у дитинстві не був діагностований, до уваги беруться різні відомості: спогади людини про дитинство та свою поведінку, академічна успішність у школі, міжособистісна взаємодія протягом життя. Відповідно до статевого чинника ГРДУ більшою мірою проявляється у хлопчиків порівняно з дівчатами, за різними статистичними даними це співвідношення коливається від 2:1 до 9:1, залежно від типу.

Значна увага у довіднику психічних розладів приділяється відокремленню ГРДУ від інших психічних захворювань, зокрема від опозиційно провокативної (викличної) поведінки, афективних розладів, антисоціальної поведінки. Опозиційна провокативна поведінка, подібна до поведінкового розладу загалом, містить протиставлення себе авторитетному оточенню, а також непокору. Водночас така поведінка не характеризується порушенням важливих соціальних норм та нанесенням фізичної шкоди іншим, як при поведінковому розладі. Тому якщо спостерігаються вищезазначені прояви, говорять радше про поведінковий розлад, 
ніж про опозиційну поведінку. У контексті ГРДУ поведінкові прояви внаслідок гіперактивності і імпульсивності також можуть мати елементи руйнівної поведінки, водночас вони не $є$ дуже деструктивними стосовно соціальних норм i правил. За умови існування такої деструкції визначаються два розлади - поведінковий і ГРДУ. Основними проявами поведінкового розладу $є$ постійні погрози оточенню, бійки, схильність до володіння зброєю та нанесення шкоди іншим, фізична жорстокість до людей і тварин, крадіжки та сексуальне насилля, нанесення шкоди майну інших, схильність до нічних походеньок та бродяжництва. Опозиційний провокативний розлад характеризується меншою руйнацією порівняно 3 поведінковим, оскільки містить прояви більше емоційного характеру: втрата самовладання, відмова виконувати доручення чи прохання авторитетних осіб, дратування інших, вияви злості і образи. Слід зазначити, що якщо визначається поведінковий розлад, то він вже включає в себе опозиційний провокативний.

Дратівливість і емоційна лабільність дітей з ГРДУ часто наближає їх до виявлення афективних проявів настрою. На противагу руйнації соціальних правил, ці розлади характеризуються частими перепадами настрою, які мають фрагментарний характер. Якщо при цьому спостерігається руйнівна поведінка стосовно соціального оточення додається також поведінковий розлад. Останній діагностується за умови постійності та повторюваності у різних життєвих контекстах. Після вісімнадцяти років цей розлад часто трансформується в антисоціальну поведінку, яка значною мірою шкодить тому оточенню, в якому вона виявляється.

В останніх дослідженнях проблема ГРДУ часто пов'язується iз екзекутивними функціями цих осіб. До таких функцій належать, передусім, здатність до формулювання цілей, їх реалізації та контролю. В сучасних нейропсихологічних дослідженнях екзекутивні функції - це гіпотетичний набір високорівневих процесів, які призначені для планування різного роду дій у відповідності із поставленою ціллю, зміни напряму діяльності в разі необхідності, а також зосередження уваги на необхідних стимулах (Khan, 2017). В останніх працях екзекутивні функції часто поєднуються із метакогніціями.

Метакогнітивні процеси актуалізуються не лише в межах безпосередньої зовнішньої дійсності людини, а й зумовлені 
внутрішніми ментальними репрезентаціями цієї дійсності (Zasiekina, 2016). Метакогнітивні процеси, які грунтуються на зовнішніх впливах навколишнього середовища, втілюються у метакогнітивних особливостях кодування та обробки інформації і розглядаються в термінах метакогнітивної перцепції. Метакогнітивні процеси іншого порядку виражаються у контролі та регуляції власних пізнавальних процесів, тому можуть трактуватись як знання та пізнання стосовно пізнавальних явищ.

Поняття метакогніції вперше отримало широке та грунтовне вивчення у концепції метапізнання Дж. Флевела (Flavell, 1979). Ключовим поняттям цієї концепції є поняття «мислення про власне мислення». Метакогніція охоплює інтелектуальне структурування та збереження інформації, інтелектуальний пошук та коригування власних дій, а також інтелектуальний контроль. Метакогнітивні процеси контролю та регуляції $є$ запланованими, зумовленими конкретною ціллю й орієнтовані на майбутню поведінку й розв'язання інтелектуальних задач.

Основою метакогніції, за Дж. Флевелом, $\epsilon$ знання про можливості та обмеження власної інтелектуальної діяльності, «це знання про архітектуру когніції та особливостей перебігу пізнавальних процесів» (Flavell, 1979: 304). Ці знання розповсюджуються на два аспекти, які й становлять організацію метакогніції: метакогнітивна перцепція та метакогнітивні стратегії. Метакогнітивна перцепція - це специфічні особливості кодування та обробки інформації; знання про власні особливості сенсорних модальностей та їх функціонування; оцінка своїх мотиваційних та емоційних станів. Метакогнітивні стратегії, на противагу когнітивним, спрямовані не стільки на досягнення цілей пізнавальної задачі, скільки на контроль та регулювання інтелектуальної діяльності.

Таким чином, вивчення метакогнітивних процесів i екзекутивних функцій на сучасному етапі виокремлюються у такі основні напрями: дослідження когнітивного контролю, вивчення особливостей саморегуляції і моніторингу пізнавальних процесів; дослідження ролі метапізнання у процесі навчання. Водночас, варто зазначити, що екзекутивні функції пов'язується iз нейрокогнітивними процесами. Зокрема важлива роль належить префронтальним ділянкам головного мозку, головно 
дорсолатеральній префронтальній корі, яка відповідає за оперативну обробку інформації в робочій пам'яті, швидкість індивідуального мовлення, ефективність абстрактного мислення.

\section{Методи і методики дослідження}

У нашому дослідженні перелік екзекутивних функцій визначався змістом діагностичних методик, які спрямовані на їх вивчення. До основних проблем, пов'язаних із екзекутивними функціями осіб з ГРДУ, належать процеси гальмування. Відтак, ГРДУ часто зумовлює надлишкову активність, яка не відповідає стимулам навколишнього середовища. Вважаємо, що труднощі 3 процесами гальмування також впливають на поглиблення проблем $з$ дислексією.

Більше того негативний вплив на дислексію здійснюють проблеми 3 робочою пам'яттю осіб $з$ ГРДУ. Вважаємо, що фонологічне усвідомлення також нерозривно пов'язане із робочою пам'яттю. Поняття фонологічної робочої пам'яті та фонологічного відтворення були введені у науковий обіг наприкінці XX століття i пов'язувалися, передусім, зі зберіганням та ефективним відтворенням фонологічної інформації. Остання досліджується на основі часу реакції при відтворенні необхідних звуків чи букв (Wagner et al., 1987).

Метою нашого емпіричного дослідження будо визначення особливості екзекутивних функцій в осіб із коморбідністю дислексії і ГРДУ та в осіб із неускладненим проявом ГРДУ. У дослідженні взяло участь 11 осіб віком від 12-16 років із Луцького i Рівненського дитячих реабілітаційних центрів, у яких було виявлено коморбідність дислексії і ГРДУ, а також 20 осіб такого ж віку і з проявами лише ГРДУ. Діагностичним інструментарієм слугували шкали для діагностики екзекутивних функцій (Executive Function Questionnaire), запропоновані А. Кханом (Khan et al., 2014). Досліджувані повинні були оцінити твердження, які стосуються труднощів у виконанні екзекутивних функцій за шкалою від 0 до 3 , де 0 - зовсім не властиві труднощі, 1 - часом відчуваю труднощі, 2 - часто відчуваю труднощі; 3 - яскраво виражені труднощі. При обрахуванні результатів для визначення відсоткового розподілу дітей, які зазнають труднощі, ми використовували відповіді, які 
оцінені у 2-3 бали. Результати дослідження екзекутивних функцій дітей із ГРДУ подано на рис. 1.

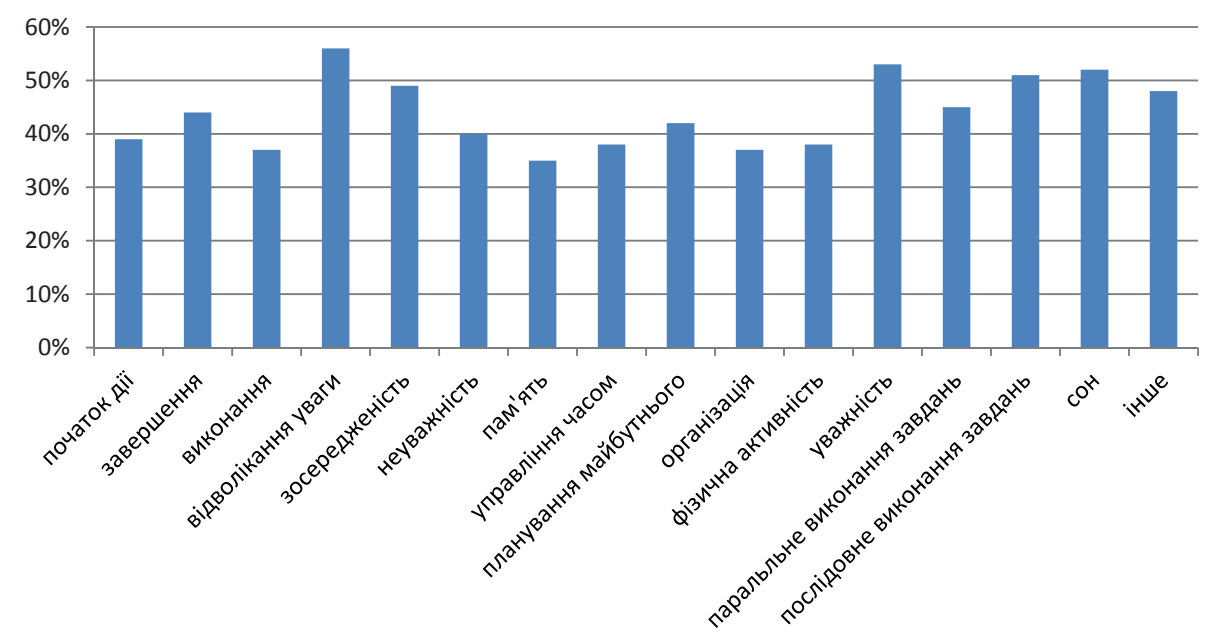

Рис. 1. Відсоток дітей з ГРДУ з проблемами екзекутивних функиій

Як видно з рисунка, найбільший відсоток дітей з ГРДУ мають проблеми із уважністю і часто відволікаються на сторонні стимули. Це також узгоджується із високим відсотком дітей, що скаржаться на труднощі у зосередженні уваги та зазначають про відсутність такої особистісної якості, як уважність.

При цьому помічаємо, що для осіб з ГРДУ важче завершити виконання завдання, ніж його почати, що також $\epsilon$ суголосним проблемам із зосередженням уваги. Доволі неочікуваними є результати стосовно труднощів у виконанні послідовних завдань ніж паралельних, що також, очевидно, пов'язано із труднощами у завершенні роботи. Таким чином, особам з ГРДУ важче даються завдання наприкінці їхнього виконання, очевидно, через малий обсяг уваги.

Для порівняння на рис. 2 подано відсоток дітей iз коморбідністю ГРДУ і дислексією, які зазначали про труднощі у здійсненні екзекутивних функцій.

Як видно 3 рисунку 2, спостерігається більший відсоток дітей із коморбідністю дислексії і ГРДУ, які зазначали про наявні труднощі в екзекутивних функціях. Помітним $є$ те, що ці діти також основні проблеми відчувають у зосередженні уваги, небажаному 
Нейрокогнітивні основи коморбідності вікової дислексї̈..

відволіканні на сторонні стимули і нерозвиненій особистісній якості - уважності. Таким чином, вважаємо, що основним симптомом досліджуваних обох вибірок $є$ неуважність. Тоді як проблеми з фізичною активністю (імпульсивністю і гіперактивністю) не є яскраво вираженими.

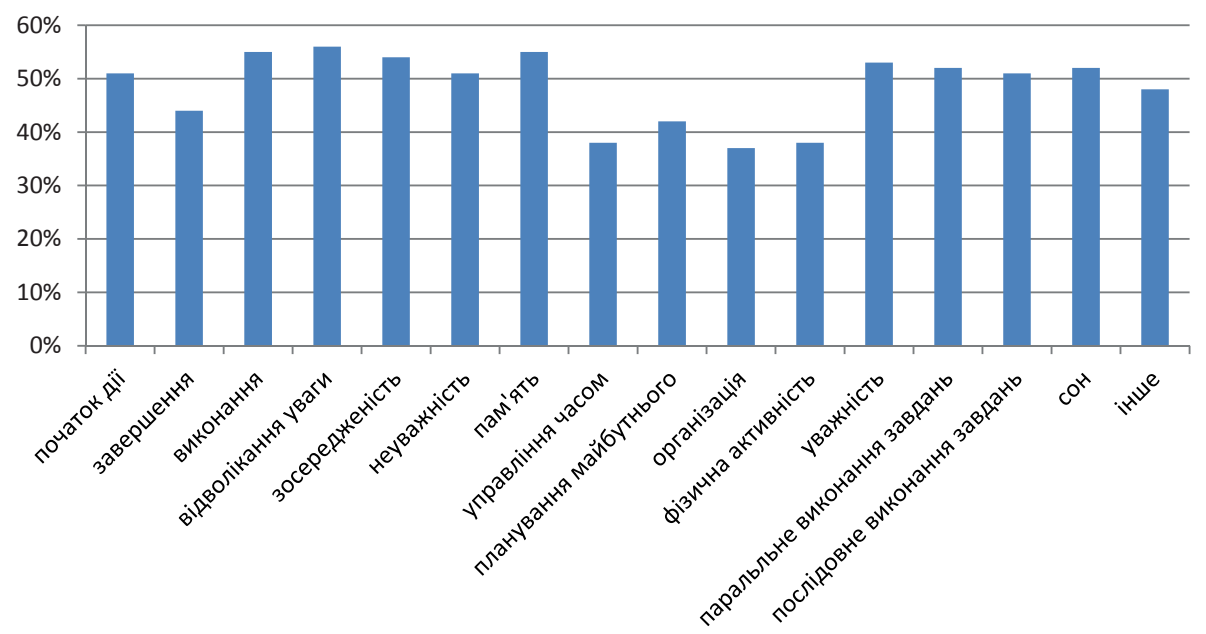

Рис. 2. Відсоток дітей з коморбідністю ГРДУ і дислексії з проблемами екзекутивних функиій

Водночас помічаємо і відмінності у здійсненні екзекутивних функцій між дітьми із ГРДУ та дітьми із коморбідністю ГРДУ i дислексії. Так, дітям із коморбідністю ГРДУ і дислексії важче розпочати певну діяльність ніж іiі завершити. Це, на наш погляд, пов'язано із труднощами у мовленнєвій діяльності, зокрема фонологічною стороною мовлення. Враховуючи важливість навчання у цьому віці, припускаємо, що дислексія поглиблює труднощі в інінціації певної активності, у якій читання виконує інструментальну функцію.

Також ці діти зазначають про труднощі, пов'зані із пам’яттю. На наш погляд, це узгоджується із проблемами фонологічної пам'яті, яка відіграє важливу роль у збереженні і відтворенні фонологічної інформації.

На наступному етапі дослідження ми здійснили дисперсійний аналіз з допомогою критерія Краскалла-Уолліса для визначення відмінностей у середньогрупових показниках екзекутивних функцій 
обох вибірок (дітей з неускладненим ГРДУ та дітей з коморбідністю дислексії і ГРДУ) (див. табл. 1).

Таблиця 1. Відмінності у прояві екзекутивних функцій дітей 3 ГРДУ та дітей з коморбідністю дислексії і ГРДУ

\begin{tabular}{llll}
\hline $\begin{array}{l}\text { Види екзекутивних } \\
\text { функцій }\end{array}$ & $\begin{array}{l}\text { Показники осіб } \\
\text { із ГРДУ }\end{array}$ & $\begin{array}{l}\text { Показники осіб із } \\
\text { коморбідністю } \\
\text { ГРДУ та дислексії }\end{array}$ & $\begin{array}{l}\text { Критерій Краскала } \\
\text { Уоллеса }\end{array}$ \\
\hdashline $\begin{array}{l}\text { Початок дії } \\
\text { Пам'ять }\end{array}$ & $\begin{array}{l}\text { П,42 } \pm 0,73 \\
\text { Паралельне виконання } \\
\text { завдань }\end{array}$ & $2,57 \pm 1,01$ & $4,20, \mathrm{p}=0,045$ \\
\hline
\end{tabular}

\section{Висновки}

Таким чином, результати емпіричного дослідження свідчать про наявність значущих відмінностей у виконанні екзекутивних функцій дітьми із коморбідністю дислексії і ГРДУ порівняно із дітьми із неускладненим ГРДУ. Таким чином, незважаючи на те, що спільними проблемами є труднощі, пов'язані із зосередженням уваги, що $\epsilon$ одним із провідних симптомів ГРДУ, важливими також є труднощі із початком активності, пам'яттю та виконанням паралельних активностей, які притаманні дітям із коморбідністю.

Перспективним вважаємо подальше нейропсихологічне дослідження осіб із коморбідністю дислексії і ГРДУ методом викликаних потенціалів для визначення голосних рідної і нерідної мови в парадигмі MMN. Невербальні еквіваленти мовленнєвих стимулів засовуватимуться у подібних парадигмах MMN i EQ. Це дасть змогу визначити, чи діти 3 дислексією відрізняються від дітей із ГРДУ у сприйнятті невербальних частот, які відповідають голосним звукам і яким чином це сприймається у випадку дислексії.

\section{Література}

American Psychiatric Association (2002). Diagnostic and statistical manual of mental disorders. Washington, DC. : American Psyhiatric Association.

August, G.J., \& Garfinkel, B.D. (1990). Comorbidity of ADHD and reading disability among clinic-referred children. Journal of Abnormal Child Psychology, 18(1), 29-45. http://dx.doi.org/10.1007/BF00919454

Barkley, R.A. (2006). Attention-deficit Hyperactivity Disorder. A handbook for diagnosis and treatment (3rd ed.). New York : The Guilford Press. https://doi. org/10.1177/1087054707305334 
Нейрокогнітивні основи коморбідності вікової дислексї...

Douglas, V.I. (1983). Attention and cognitive problems. In M. Rutter (Ed.), Developmental neuropsychiatry (pp. 280-329). New York : Guilford Press.

Gadow, K.D., \& Nolan, E.E. (2002). Differences between preschool children with ODD, ADHD, and ODD+ADHD symptoms. Journal of Child Psychology and Psychiatry, 43, 191-201. PMID:11902598

Flavell, J.H. (1979). Metacognition and cognitive monitoring: A new area of cognitivedevelopmental inquiry. American Psychologist, 34, 906-911. http://dx.doi. org/10.1037/0003-066X.34.10.906

Khan, A., Abdal-hay, A., Qazi, T., Calle, C.L., \& Castillo, R.C. (2014). Time estimation in developmental dyslexia: An experimental investigation. Open Journal of Medical Psychology, 3, 373-381. http://dx.doi.org/10.4236/ojmp.2014.35039

Khan, A, Loberg, O., \& Hautala, J. (2017). On the eye movement control of changing reading direction for asingle word: The case of reading numerals in urdu. Journal of Psycholinguistic Research, 46(5), 1273-1283. DOI: 10.1007/ s10936-017-9491-1

Kulkarni, M. (2015). Attention deficit hyperactivity disorder. Indian Journal of Paediatrics, 82(3), 267-271. doi: 10.1007/s12098-014-1556-7

Wagner, R.K., \& Torgesen, J.K. (1987). The nature of phonological processing and its causal role in the acquisition of reading skills. Psychological Bulletin, 101, 192 212. http://dx.doi.org/10.1037/0033-2909.101.2.192

Willcutt, E.G, Pennington, B.F, Olson, R.K, Chhabildas, N, \& Hulslander, J. (2005). Neuropsychological analyses of comorbidity between reading disability and attention deficit hyperactivity disorder: In search of the common deficit. Developmental Neuropsychology, 27, 35-78. DOI:10.1207/s15326942dn2701_3

Zasiekina, L. (2009). Speech and Language of Children with Attention Deficit and Hyperactivity Disorder. Bulgarian Journal of Psychology, 3-4, 393-404.

Zasiekina, L. (2012). Psycholinguistic Approach to Attention Deficit and Hyperactivity Disorder (ADHD). In G. Minini \& A. Manuti (Eds.), Applied Psycholinguistics: Positive Effects and Ethical Perspectives (Vol. II) (pp. 241-251).

Zasiekina, L. (2016). Individual intelligence in the conext of modern psycholinguistic studies. Journal of Russian and East European Psychology, 53(4), 68-88. https:// doi.org/10.1080/10610405.2016.1251112

\begin{abstract}
АНОТАЦІЯ
Коморбідність вікової дислексії і ГРДУ $\epsilon$ доволі поширеною. Діти з такою коморбідністю вирізняються глибшою нейрофізіологічною дисфункцією порівняно із дітьми, які мають один розлад: лише ГРДУ чи вікову дислексію. Вікова дислексія - че специфічна нездатність оволодівати навичками читання і письма при збереженні нормальних інтелектуальних здібностей та соціокультурної адаптації. Незважаючи на наявність різних підходів до вивчення вікової дислексії: теорії фонологічного дефіциту короткотривалої вербальної пам'яті, когнітивно-графрічної сегментації тексту і т. ін., найпоширенішим підходом є вивчення дислексії як здатності індивіда до фонологічного усвідомлення.
\end{abstract}


Neuro-cognitive Underpinning of Co-morbidity between...

ГРДУ - це розлад, провідними діагностичними критеріями якого $\epsilon$ постійний і довготривалий прояв неуважності ma імпульсивності. Також зустрічаються типи лише з деріцитом уваги, або лише $з$ імпульсивністю і гіперактивністю.

Висока частотність коморбідності вікової дислексії і ГРДУ дає змогу зробити припущення про спільні нейрокогнітивні механізми цих розладів. Існують кілька припущень стосовно такого поєднання двох розладів: симптоми ГРДУ сукупно з дислексією є похідними від проблем у мовленнєвій діяльності читанні (гіпотеза фенокопії), як когнітивне порушення (гіпотеза когнітивного розвитку).

Висока частотність коморбідності вікової дислексії і ГРДУ, існування теоретичних гіпотез щодо такого поєднання, можливість емпіричного дослідження на основі екзекутивних функцій дали змогу виявити нейрокогнітивні основи цих розладів, що полягають у дисфункції дорсолатеральної префронтальної кори, а на рівні екзекутивних функцій - у порушеннях фонологічної робочої пам'яті, ініціації діяльності та виконанні паралельних активностей. Досліджувані обох вибірок виявили найбільші труднощі у зосередженні уваги і легкому відволіканні на сторонні стимули, тоді як проблеми імпульсивності $і$ гіперактивності не була переважаючою в осіб із коморбідністю ГРДУ і дислексії.

Ключові слова: ГРДУ, дислексія, коморбідність, нейрокогніція, читання, екзекутивні функиії.

\section{Засекина Лариса. Нейрокогнитивные основы коморбидности возрастной дислексии и гиперактивного расстройства с дефицитом внимания (СДВГ)}

\section{АННОТАЦИЯ}

Коморбидность синдрома гиперактивного расстройства с дерицитом внимания (СДВГ) и дислексии является распространённым явлением. Дети с такой коморбидностью отличаются глубокой нейрофизиологической дисфункцией по сравнению с детьми, имеющими одно расстройство СДВГ или дислексию без осложнений. Возрастная дислекия - это специфическая неспособность овладевать навыками чтения и письма при сохраненных интеллектуальных способностях и социокультурной адаптации. Несмотря на наличие разных подходов к изучению дислексии: теории фонологического дефицита кратковременной вербальной памяти, когнитивно-графической сегментации текста и т.д., наиболее распространенными являются исследования дислексии как способности фонологического осознания. 
Нейрокогнітивні основи коморбідності вікової дислексї̈..

СДВГ - это расстройство, основными симптомами которого является невнимательность и импульсивность продолжительного и постоянного характера. Однако различаются типы, основывающиеся только на одном из симптомов - импульсивности, гиперрактивности или невнимательности. Высокая частотность коморбидности дислексии и СДВГ дает основания предположить наличие общих нейрокогнитивных механизмов для дислексии и СДВГ. Существует несколько предположений такого характера: сочетание дислексии и СДВГ обусловлены проблемами в речевой деятельности, в частности чтения; сочетание дислексии и СДВГ обусловлены когнитивными расстройствами (теория когнитивного развития).

Высокая частотность коморбидности дислексии и СДВГ, анализ теоретических гипотез относительно такого сочетания, возможность эмпирического исследования на основе экзекутивных функций позволили выявить нейрокогнитивные основания, представленные дисфункцией дорсолатеральной префронтальной коры, а на уровне экзекутивных функций - нарушениями фонологической рабочей памяти, инициации деятельности и выполнения параллельных активностей. Исследуемые обеих выборок (с коморбидностью дислексии и СДВГ и неусложненном СДВГ) испытывают самые большие трудности с концентрацией внимания и его отвлечении на второстепенные стимулы. В то же время проблемы с гиперактивностью и импульсивностью не являются ярко выраженными.

Ключевые слова: СДВГ, дислекия, коморбидность, нейрокогниция, чтение, экзекутивные функции. 